\title{
Nano Chemotherapeutics in Bone Metastasis and Targeting
}

\author{
Kemik Metastazlarında Nano Kemoterapötikler ve Hedeflendirilmeleri
}

\author{
Müge KILIÇARSLAN*, Miray GÖRGÖZ \\ Ankara University, Faculty of Pharmacy, Department of Pharmaceutical Technology, 06100 Tandoğan, Ankara, TURKEY
}

\begin{abstract}
Due to the increase of cancer incidence in recent years, contemporary studies have focused on the identification, diagnosis and treatment of this disease. It is rather difficult to treat cancer without harming normal cells. Thus, studies exploring nano systems that are targeted to the cancerous cells are drawing attention. The frequent formation of metastasis in the bone tissue of certain cancers, such as the breast and prostate, has increased the mortality risk from these cancers. For this reason, preventing metastasis by targeting metastatic bone tissue with anti-neoplastic agents without damaging healthy soft tissue has become a subject of interest for many researchers. In addition to the therapeutic properties of bisphosphonates for bone metastases that form osteoclastic and osteoblastic, its affinity to hydroxyapatite, the main mineral of bone tissue, has been extensively studied as a targeting agent for bone diseases. With the conjugation of bisphosphonates to the nanoparticulate systems, nanoparticles loaded with the active ingredient are transmitted solely to the diseased bone tissue. Then, with the help of a nanostructured system, the bisphosphonates are localized only in the tumor containing diseased bone tissue, and the chemotherapeutic agent is released in a controlled manner. In this review, current approaches targeting bone metastases, and especially studies conducted with nanostructured drug carrier systems, are assessed.
\end{abstract}

Key words: Nano chemotherapeutics, Bone metastasis, Bisphosphanates, Nanoparticles, Drug targeting

\section{ÖZ}

Kanser hastalığının son yıllarda artan insidansı nedeniyle güncel çalıșmalar bu hastalığın tanı, teşhis ve tedavisi üzerine yoğunlașmıștır. Normal hücrelere zarar vermeden hastalığın tedavisi oldukça güçtür. Bu nedenle sadece kanserli hücreye hedeflendirilmiş nano sistemler ile yapılan çalışmalar dikkat çekmektedir. Yaygın olan meme ve prostat kanserleri gibi hastalıkların metastazının sıklıkla kemik dokusunda meydana gelmesi hastanın yașam kalitesini azaltmasından öte bu kanser türlerinin ölüm riskini artırmaktadır. Bu amaçla sağlıklı yumuşak dokuya zarar vermeden anti-neoplastik ajanların doğrudan metastaz meydana gelmiş kemik dokusuna hedeflendirilmesi ile metastazın önlenmesi veya tedavisi çoğu araştırıcının üzerinde çalıştığı konular arasına girmiştir. Osteoklastik veya osteoblastik şekilde oluşan kemik metastazları için bifosfonatların tedavi edici özelliklerine ek olarak kemik dokusunun ana minerali olan hidroksiapatite olan afinitesi nedeni ile kemik hastalıkları için hedefleme ajanı olarak da oldukça yaygın şekilde çalıșma konusu olmuştur. Bifosfanatların nanopartiküler sistemlere konjugasyonu ile de etkin madde yüklü nanopartiküller sadece hasta kemik dokusuna iletilmekte, nano yapı sayesinde de sistemin tümörlü dokuda lokalize olup kemoterapötik ajanı kontrollü olarak salması sağlanmaktadır. Bu derleme ile kemik metastazlarına hedeflemedeki güncel olan yaklaşımlar, özellikle nano yapılı ilaç taşıyıcı sistemler ile yapılan çalışmalar tartışılarak değerlendirilmiștir.

Anahtar kelimeler: Nano kemoterapotikler, Kemik metastazı, Bifosfonatlar, Nanopartiküller, illaç hedefleme

\section{INTRODUCTION}

Recent developments in nanotechnology have advanced the direction of biomedical applications and the optimization of therapies. Nano chemotherapeutics have continued to be the center of interest due to several distinguishing attributes, including: the surface area of their delivery systems, which is greater than a micrometer; several unique structural properties; high residency time in the circulatory system; configurability for the diagnosis and treatment of many diseases; ability to target various bioactive agents and organs; ability to travel in the tissue through capillaries; and their relatively easy uptake by the cells. Especially the production of nanoparticles that can deliver chemotherapeutic agents to cancerous tissues and thus, blocking the inadequate selectivity of conventional cancer drugs are very promising (1-3). Aside from their targeting ability, another property that attracts attention of nanoparticles is their ability to facilitate the delivery of different chemotherapeutic agents together, thereby increasing the efficiency of the treatment (4). 
Bone diseases are disorders related to the skeletal system and include disorders that restrict basic movements. These disorders disrupt the balance between bone resorption and formation (5). Since there is no effective treatment for multiple bone disorders, such as arthritis, osteoarthritis, osteosarcoma, and metastatic bone cancer, new drugs and new drug delivery systems that performed efficiently and safely in clinical treatments must be developed immediately. However, for most of bone diseases that cause bone disturbances, such as bone cancer, the main concern is maintaining a balance between the efficiency and the adverse effects of the treatment (6). To address this, conducted studies have revealed that a potential strategy in order to increase treatment efficiency is the preparation and application of targeted nano technological systems. Although nano systems have not yet been clinically used for the treatment of bone cancer, studies about the design of multifunctional nanoparticles in the treatment of multiple bone diseases are encouraging.

\section{RESULTS AND DISCUSSION}

\section{Bone metastasis and treatment approaches}

The spread of cancer from its initiation site to other parts of the body is called as metastasis. Metastasis occurs when cells separate from the tumor and spread to other parts of the body, either through blood circulation or the lymph ducts, as shown in Figure 1. With this movement, cancer cells can spread to distant tissues and organs. While many cancer cells that separate from the main tumor disappear without causing any harmful effects, some of them settle in new areas and start to proliferate and form new tumors (7). Most of the cancer patients dies from tumor cells that have caused metastasis in other parts of the body (8-10). However, different types of cancer have different dispositions toward different body areas, with the most extensive metastasis observed in the liver, lung, brain and bone $(7,11)$.

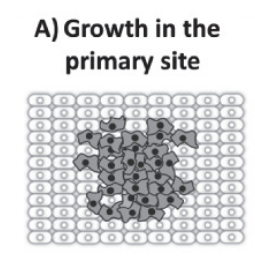

C) Circulation

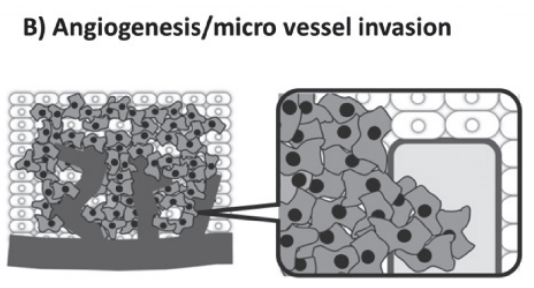

D) Arrival at the secondary organ / extravasation

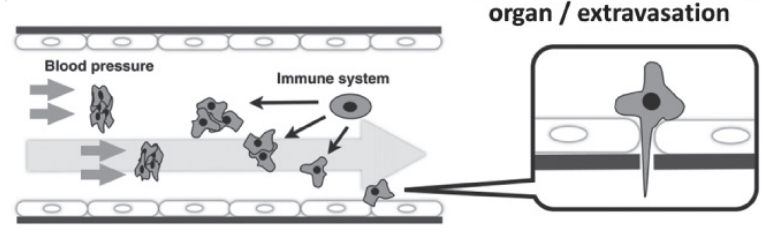

Figure 1. Metastasis stages of cancerous cells A) Proliferation of the tumor in primary area B) Increase of vascularization and transfer of tumor cells into capillaries C) Participation of tumor cells into blood circulation D) Arrival of tumor cells in secondary area where vascularization and extravasation will occur (figure was used with permission of researchers) (22)
When the cancer spreads to the bone, this is referred to as "bone metastasis". Some cancers begin in the bone and are called primary bone cancers, such as osteosarcoma, chondrosarcoma, and Ewing's sarcoma. Especially in adults, bone metastasis is observed more often than bone cancer. Furthermore, tumors that cause breast, lung, and prostate cancer usually metastasize in the bones (6,7,12-15).

The skeletal system is the basic framework of the body and is composed of bone tissue, which consists of a fibrous collagen structure, and calcium phosphate minerals. Hydroxyapatite is the main mineral component of bones. These minerals confer to the bone rigidity and strength for carrying the body by attaching the cells (16-18). Bone tissue harbors two basic cells in its structure-osteoblasts that allow the formation of new bone and osteoclasts that degrade aged bone. The degradation of old cells and the formation of new bone tissue are synchronous processes. Through these two mechanisms, bone tissue preserves its strength (19-21).

It is generally agreed that due to its rich nourishment and stable environment, tumors migrate to bone (23). Additionally, adhesive molecules produced by tumor cells facilitate their binding to the bone. As a result of this adhesion, the production of angiogenic and bone resorbing factors increase, thereby accelerating the proliferation of the tumor in bone tissue. Furthermore, the bones fulfill the storage function for several growth factors. These growth factors are actively released during bone resorption, forming an environment where tumor cells can develop and proliferate. This phenomenon is explained by the "seed and soil" theory $(21,24)$.

The aim of treatment is to prevent tumor growth and eliminate symptoms. Treatment is applied either systemically or locally, with the former preferred in cases where the cancer has spread to more than one bone. However, local treatment is

Table 1. Advantages and disadvantages of nanosystems used in targeting $(28,30,32)$

\begin{tabular}{|c|c|}
\hline Advantages & Disadvantages \\
\hline $\begin{array}{l}\text { - Longer residence time in } \\
\text { blood circulation } \\
\text { - Ability to localize in the } \\
\text { cancerous area because } \\
\text { of higher permeation and } \\
\text { retention properties of the } \\
\text { neoplastic tissue } \\
\text { - Reconstructability } \\
\text { - Allowance of polymeric } \\
\text { nanoparticles to multifaceted } \\
\text { modification (such as } \\
\text { surface modification with } \\
\text { polyethylene glycol [PEG]) } \\
\text { - Ability to directly adhere to } \\
\text { the tumor by employing the } \\
\text { ligands, which have different } \\
\text { affinities to biological targets } \\
\text { in active targeting }\end{array}$ & $\begin{array}{l}\text { - Although nanoparticles have an } \\
\text { affinity to accumulate in the tumor } \\
\text { area, their efficiency is dependent upon } \\
\text { their complete release of the active } \\
\text { substance } \\
\text { - Weak tumor penetration of } \\
\text { nanopharmaceuticals } \\
\text { - Complexity of nanoparticle design and } \\
\text { active targeting that can be beneficial } \\
\text { in a potential application for a specific } \\
\text { therapy } \\
\text { - Lack of combined nanoformulation } \\
\text { applications that comply with the diet } \\
\text { combinations that are applied in clinical } \\
\text { usage (difficulty preparing a patient- } \\
\text { specific combination) } \\
\text { - Passage requirement of some } \\
\text { biological membranes, muscle tissue } \\
\text { and fibroblast-based cell layers between } \\
\text { cancer cells and endothelial cells }\end{array}$ \\
\hline
\end{tabular}


preferred when the cancer has spread to only one bone or a small area. Systemic treatments can be provided through hormone therapy, chemotherapy and the administration of drugs orally or via injection. While radiotherapy and surgical procedures are mostly utilized for local therapy (25), in cancer types that have specifically spread to the bone, radiopharmaceuticals and bisphosphonates are used, and at times, systemic and local therapies are used in conjunction. Targeted drugs follow the cancer cells directly; therefore, healthy normal cells are not damaged during treatment. These types of drugs can also be combined with chemotherapy and hormone therapy (25-28).

\section{Nanosystems and tumor targeting}

Nanotechnological targeting can be performed actively or passively. Some advantages and disadvantages of using nanosystems to target tumor tissue are shown in Table 1. Some of the passively targeted nanopharmaceuticals that have been approved for clinical usage include Myocet ${ }^{\circledR}$, Doxil ${ }^{\circledR}$, Daunoxome ${ }^{\circledR}$, Abraxane $^{\circledR}$ and Genexol-PM ${ }^{\circledR}(1,29)$. Because of being largely impossible to facilitate the accumulation of active substances in the impact area with passive targeting, researches tend to be directed toward actively targeted nano-formulations. With active targeting in cancer therapy, transmitting toxic drugs to healthy tissue is minimized or eliminated, and the therapeutic efficacy of actively targeted nanoparticles is higher than non-targeted nanoparticles (30). Some external stimulants, such as light, heat, ultrasound waves, and magnetic areas are applied in order to release of drug to the areas desired to be affected to eliminate disadvantages of targeted nanosystems. These systems are called triggered release systems $(1,31)$.

\section{Targeting of nano chemotherapeutics to the bone}

Bisphosphonates are the predominant group used in the treatment of bone metastasis and bone targeting (33-35).
Bisphosphonates have high bone affinity and are released into bone tissue by instilling or grafting them over the nanoparticles that are loaded with other active substances (6,36). Table 2 lists some examples of active substances, ligands, and production methods which are used in different nanosystems (nanoparticle, dendrimer, liposome, and nanocomplex) for bone targeting.

Biological activity of bisphosphonates was first discovered in 1968, and they were soon prescribed to treat osteoporosis (21). These drugs effect by slowing down the activity of the osteoclast cells and, therefore, are especially effective in treating osteoclastic metastasis $(7,33,37)$. They are also effective in terms of reducing apoptosis related to cell permeability, and they reduce the capillary vascularization of endothelial tissue (21). Bisphosphonates can reduce cancer related bone pain, bone damage, and high blood calcium concentrations; they are also capable of averting bone fractures (10). Because they show high affinity towards bone, bisphosphonates are generally utilized as imaging agents conjugated with radiopharmaceuticals. Furthermore, they can be conjugated with active substances such as estradiol, prostaglandin, diclofenac, fluoroquinolone, cisplatin, methotrexate, technetium hydroxyethylene diphosphonate, technetium methylene diphosphonate, samarium, lexidronam. Peptides and proteins have also been conjugated with bisphosphonates for bone targeting (10,14,21,43-45).

Utilizing bisphosphonates for the targeting of nanoparticulate systems has many advantages. Nitrogenous bisphosphonates contain primer amines and carboxylic acid. If they are conjugated with the nanoparticle via degradable bonds, they become pharmaceutically active and will even show synergy with a suitable active substance (21).

\begin{tabular}{|c|c|c|c|c|c|c|}
\hline Formulations & Ligands & $\begin{array}{l}\text { Active ingredi- } \\
\text { ents }\end{array}$ & Polymer/Lipid & $\begin{array}{l}\text { Production } \\
\text { method }\end{array}$ & Particle size & Ref. \\
\hline $\begin{array}{l}\text { Nano structured ceramic } \\
\text { implants }\end{array}$ & $\begin{array}{l}\text { Calcium phosphate } \\
\text { and hydroxyapatite }\end{array}$ & - & - & Precipitation & $\begin{array}{l}8.84 \mu \mathrm{m} \text { and } \\
5.21 \mu \mathrm{m}\end{array}$ & (38) \\
\hline Nano complex & Hydroxyapatite & $\begin{array}{l}\text { BMP-2 } \\
\text { Titanium }\end{array}$ & - & $\begin{array}{l}\text { Ionic interac- } \\
\text { tion }\end{array}$ & $150-250 \mathrm{~nm}$ & (39) \\
\hline Nanoparticle & Hydroxyapatite & - & - & Precipitation & $20-40 \mathrm{~nm}$ & (18) \\
\hline Nanoparticle & Alendronate & Estrogen & $\begin{array}{l}\text { Polyethylene glycol- Poly(lactic-co-glycolic } \\
\text { acid) block copolymer }\end{array}$ & $\begin{array}{l}\text { Dialysis } \\
\text { method }\end{array}$ & $43.5-57.3 \mathrm{~nm}$ & $(40)$ \\
\hline Dendrimer & Alendronate & Paclitaxel & Hydroxypropyl methacrylamide (HPMA) & Conjugation & $95 \mathrm{~nm}$ & (41) \\
\hline Dendrimer & Alendronate & Paclitaxel & Polyethylene glycol & Conjugation & $190 \mathrm{~nm}$ & (23) \\
\hline $\begin{array}{l}\text { Radiopharmaceutics and } \\
\text { bisphosphonate complex }\end{array}$ & $\begin{array}{l}\text { Hydroxyethylidene- } \\
\text { 1,1-diphosphonate }\end{array}$ & $\begin{array}{l}\text { Rhenium-186 } \\
\left({ }^{186} \mathrm{Re}\right)\end{array}$ & - & Conjugation & - & (42) \\
\hline Liposome & RGD peptide & Cisplatin & $\begin{array}{l}\text { Phosphatidylcholine, cholesterol, } \\
\text { 1,2-distearoyl-sn-glycero-3- } \\
\text { phosphoethanolamine-N-[maleimide (poly- } \\
\text { ethylene glycol)-2000] }\end{array}$ & $\begin{array}{l}\text { Extrusion of } \\
\text { suspensions }\end{array}$ & $214.7 \mathrm{~nm}$ & (9) \\
\hline
\end{tabular}


Zoledronic acid (ZOL) is a nitrogen-containing bisphosphonate with anticancer activity. ZOL increases apoptosis, prevents the formation of new veins that will ensure the blood supply to the tumor, decreases the level of vascular endothelial growth factor (VEGF), and decreases substance adhesion activity towards the tumor and osteoclast cells. Chaudhari et al. developed targeted drug release systems for bone metastasis containing docetaxel loaded nanoparticles formed from PLGA (poly(lactic-co-glycolic acid)), which have been approved by the FDA for use with ZOL on humans. In this study, nanoparticles were prepared by forming a PLGAPEG-ZOL conjugate. According to the results obtained from the in vitro drug release experiments, the release model is biphasic. The initial burst release was due to the release of drug located on and near the surface of the nanoparticles. In the second phase, the release was slower and controlled by diffusion rate of drug across the polymer matrix. In addition, as a result of the bone affinity tests, no significant differences were observed in bone adhesion between the conjugate nanoparticles and the solutions containing only ZOL. The distribution of radiolabeled particles among the body and bone affinity of these particles were compared with the blood concentrations of the PLGA-PEG-ZOL nanoparticles. At the end of 24 hours, it was observed that 50 times more PLGAPEG-ZOL conjugate was present in the bone compared to PLGA-PEG nanoparticles. Furthermore, the bone adhesion ratio of the PLGA-PEG-ZOL nanoparticles was found 3.5 times increased compared to normal bone. The authors postulated that the reason for this phenomenon was the loss of lining wherein surrounds the healthy bone in diseased bone tissue. This lining prevents zoledronate from binding, thus its affinity to diseased tissue (osteoporosis, bone metastasis, etc.) is much higher (10).

$\mathrm{Li}$ et al. stated that prostate cancer, believed to be osteoblastic, shows osteolytic character at the initial stage of bone metastasis. Therefore, they argued that by targeting to the bone metastasis area that contains both osteolytic and osteoblastic drug molecules, the bone tumor related alterations will be prevented (14). In another study, researchers produced nanoparticles conjugated with alendronate (ALE) for calcification, which is a pathological bone metastasis in vivo. Calcification forms as a result of the deposition of calcium in normal tissues, such as veins, nerves and breast tissues, which is similar to embryonic osteogenesis. Generally, lesions formed as a result of calcification are benign; however, in prostate and breast cancer, this situation is reversed. It has been observed that surface of the nanoparticles formed for this purpose is primarily covered with polydopamine, which provides adhesive properties, and conjugation of the particle surface is facilitated. Then, ALE can easily be conjugated with the particle surface, ensuring that it will act as both an active substance and a targeting agent (46).

In a study conducted by Clementi et al. (2011), ALE and paclitaxel (PTX) were prepared in dendrimer form together and separately, and conjugates were obtained. The purpose of this study was to investigate the effect of PEG when used as a carrier on cytotoxic PTX and ALE. Active targeting to the bone by virtue of ALE and passive targeting with an endothelial permeation retention effect were successful. In addition, by increasing the dimensions of the PEG conjugation relative to the free drug, the deposition in the tumor tissue increased (23). In another study by the same research group, bone metastasis caused by breast cancer was targeted using micelles with a dendrimer structure. Cell culture experiments were performed using preparation of the same conjugates over MDA-MB-231 human breast cancer cells and 4T1 mouse breast cancer cells. For both cell types, conjugate formation did not cause any loss of effect. In addition, in vivo antitumor activity determination study showed that after 15 days, the highest tumor healing could be provided with the PTX-PEGALE conjugate. Deposition in the tumor was monitored by using a non invasive monitoring system, and at the end of 8 hours, the PTX-PEG-ALE conjugate showed the highest deposition. When the distribution in the body was investigated, it was found that the PTX-PEG-ALE conjugate bound to the tumor with a higher ratio than the conjugate formed between PTX and ALE or PTX and PEG (12).

In another study, H40-star-PEG/ALE micelles were obtained and targeted delivery of doxorubicin to the bone was successful. In this micelle, H4O polyester formed the hydrophobic nucleus part and served as storage for the hydrophobic active substance. ALE was the bone targeted fragment. PEG formed the hydrophobic arms of the star shaped micelle. Release profiles of the micelles loaded with doxorubicin were investigated at $\mathrm{pH} 4$ and $\mathrm{pH}$ 7.4. For both $\mathrm{pH}$, the burst effect was quiet fast. The release rate observed in $\mathrm{pH} 5$ was faster than the physiological $\mathrm{pH}$. The reason for these differences was protonation of the amino group of doxorubicin in an acidic environment and low speed degradation of the micelle nucleus at low $\mathrm{pH}$. The authors stated that this drug release rate was promising for $\mathrm{pH}$ dependent release systems to bone tumors (43).

Miller et al. aimed to facilitate the targeting of PTX to bone by utilizing ALE. Owing to conjugation with the N-(2Hydroxypropyl) methacrylamide (HPMA) copolymer, PTX was targeted to metastatic bone regions. It was determined that the passage of the conjugate from the leaking tumor area and its exit from the exterior of the vein were passive. Furthermore, a normal blood vein would not allow the conjugate to pass due to its size; thus, it was ensured that the conjugate would only target the tumor area. HPMA can be dissolved in water and is among the carriers that are biocompatible and non-toxic, and it does not stimulate the immune system. These macromolecules do not diffuse in normal blood veins, but they selectively accumulate in tumor areas because of the increased permeability and retention (IPR) effect. In addition, since the blood brain barrier cannot be overcome with this conjugation, the neurotoxic side 
effects formed by PTX are prevented, and residence time in the circulation is extended (41).

Currently, the most popular nano systems for local substance release are magnetic nanoparticles. The disadvantage of these methods is low target cell selectivity, and the requirement to place the patient in a magnetic area for long periods of time (23). One study observed the effect of magnetic nanoparticles on in vitro osteoblasts, and according to the cell culture results collected on the fifth and eighth days, it was found that $\gamma-\mathrm{Fe}_{2} \mathrm{O}_{3}$ magnetic nanoparticles significantly increased osteoblast density compared to the control group. Then, these nanoparticles were coated with calcium phosphate for the treatment of bone disorders, and in order to prevent agglomeration, were distributed in bovine serum albumin or citric acid. With the presence of this coating inside the bovine serum albumin, by day one, osteoblast density had significantly increased compared to the control group (47).

The performed studies show that modifying the polymeric structure does not significantly increase the targeting binding ratio of processes to the bone tissue, but the presence of the higher binding affinity ligands increased the adsorption. Moreover, it was stated that multiple types of ligand conjugations give better bindings. However, increasing number of the ligands in the nanostructure and increasing the ligand size are not advantageous, once the size of nanoparticles is increased then nanoparticles cannot be used in every formulation $(21,48)$.

When metastasis is generated in bone, acid base balance of the tissue where metastasis is formed is disturbed, due to the protons and hydrolases that are given to the medium by the osteoclast cells. Here, the organic and mineral structure of the bone matrix disintegrates, and the $\mathrm{pH}$ decreases to 4.5 in the medium where bone resorption occurs. Because of this, $\mathrm{pH}$ sensitive bone specific drug release systems have drawn

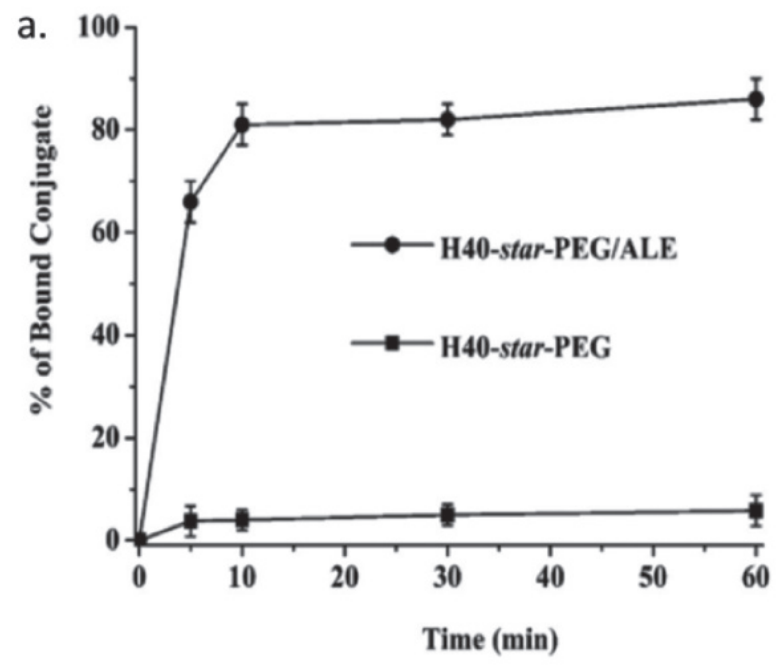

Figure 2. H-40-star-PEG/ALE and H-40-star-PEG micelles in vitro bone binding kinetics (figure was used with permission of researchers) (43) considerable attention. Ye et al. obtained ALE-monoethyl adipate-(hydrazone)-doxorubicin conjugate by conjugating monoethyl adipate, ALE, and doxorubicin with an amide bond and a hydrazone bond, respectively. It was determined that with conjugation, binding of doxorubicin to the bone increased significantly. In addition, the authors found that in in vitro release tests conducted under different $\mathrm{pH}$ conditions, a $\mathrm{pH}$ dependent release was observed in conjugates with the hydrazone bond, but not in conjugates with the amide bond (49).

\section{Bone binding and drug release}

In bone targeted systems, in vitro binding tests are performed by determining the binding of particles to hydroxyapatite. These tests are generally based on the addition of a nanoparticle suspension over bone powder or hydroxyapatite in a test tube. Then, the mixture is incubated, and after a predetermined period of time, centrifuged. The particular system is then analyzed inside the supernatant using a suitable analysis method (48). A binding test was performed using the above mentioned method. Figure 2 shows a graph comparing the bone binding capacities of micelles that were conjugated with ALE and those which were not conjugated with ALE. It shows that the bone binding ratio of the nano sized conjugate formed with ALE was $70 \%$ after 5 minutes, while the conjugates not bound with ALE showed no significant binding (43).

In another study bone binding kinetics of nanoparticles conjugated with ZOL and ZOL solution was investigated and it was determined that the utilization of ZOL as nanoparticle surface ligand did not cause any effect loss in terms of bone binding (10).

In vitro drug release studies are generally performed in buffer mediums that mimic $37^{\circ} \mathrm{C}$, lysosomal ( $\left.\mathrm{pH} 5\right)$, and physiological mediums ( $\mathrm{pH} 7.4$ ) with the incubation of a sufficient amount of conjugate in a proper way $(23,43)$. Chen et al. investigated the

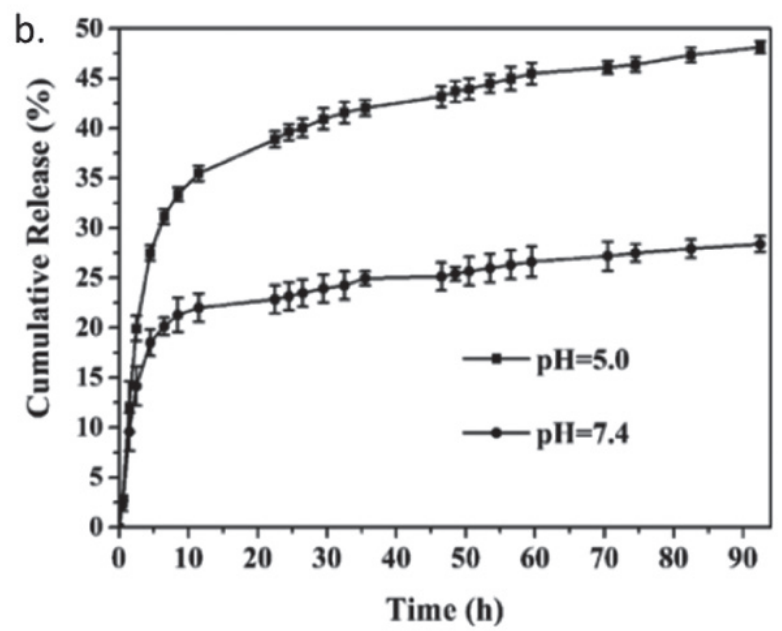

Figure 3. In vitro active substance release graphic of doxorubicin loaded Boltorn H40-PEG conjugate, which was conjugated with ALE in $\mathrm{pH} 5.0$ vs. $\mathrm{pH} 7.4$ buffer mediums (figure was used with permission of researchers) (43) 
in vitro drug release rate of doxorubicin loaded Boltorn-H40PEG conjugate, which was conjugated with ALE by incubating it in $\mathrm{pH} 5$ and $\mathrm{pH} 7.4$ buffer mediums. According to the obtained results (Figure 3), $\mathrm{pH}$-dependent drug release was observed in the established particulate. These results showed that the obtained micelles could provide more efficient treatment at the tumor containing area of the bone (43).

Although the in vitro drug release studies will give information about release rate, the antineoplastic effect in the metastatic tissue cannot be analyzed in these tests. In addition, even though a reduction in the tissue containing tumor can be observed in the in vivo experiments, whether the anticancer agent harms the healthy cells cannot be determined or not. Therefore, conducting cell culture experiments is important to show that targeting can be performed. It is important to prove that the nanoparticles do not show a non-proliferative effect on healthy cells, with regard to showing that the prepared system does not harm healthy tissue. For non healthy cells that develop bone metastasis, generally sarcoma, breast or prostate cancer cells are used $(9,23,46,50)$.

\section{CONCLUSION}

As a result of the review we performed, it is determined that the most frequently used approach for targeted delivery of anticancer agents to areas containing tumors in the bone is conjugation of bisphosphonates to nano particulate systems. Bisphosphonates' affinity to hydroxyapatite shows that these molecules are ideal molecules for bone targeting. This conjugation was generally formed by conjugating bisphosphonates to the particle surface. The usability of bisphosphonates as active substances, especially in osteoclastic metastasis, make these molecules advantageous. Concurrently, it was shown in many studies that both the targeting and the anticancer effect of the active substance of bisphosphonates, such as zoledronate, ZOL and ALE, which were bound to nanoparticles loaded with active substances used for the treatment of cancer, can be increased with a synergic effect. Nano particulate systems that are conjugated with bisphosphonates and/or other ligands with bone affinity are promising therapies in the treatment of bone cancer or bone metastasis, as well as other bone diseases.

\section{REFERENCES}

1. Sanna V, Pala N, Sechi M. Targeted therapy using nanotechnology: focus on cancer. Int J Nanomedicine 9, 467-83, 2014.

2. Cegnar M, Kristl J, Kos J. Nanoscale polymer carriers to deliver chemotherapeutic agents to tumours. Expert Opin Biol Ther 5(12), 1557-69, 2005.

3. Wang $M$, Thanou M. Targeting nanoparticles to cancer. Pharmacol Res 62(2), 90-9, 2010.

4. Kemp JA, Shim MS, Heo CY, Kwon YJ. “Combo" nanomedicine: Codelivery of multi-modal therapeutics for efficient, targeted, and safe cancer therapy. Adv Drug Deliv Rev 98, 3-18, 2016.
5. Rodan GA, Martin TJ. Therapeutic approaches to bone diseases. Science 289(5484), 1508-14, 2000.

6. Gu W, Wu C, Chen J, Xiao Y. Nanotechnology in the targeted drug delivery for bone diseases and bone regeneration. Int $\mathrm{J}$ Nanomedicine 8, 2305-17, 2013.

7. American Cancer Society, Bone Metastasis. 2014.

8. Mundy GR. Metastasis to bone: causes, consequences and therapeutic opportunities. Nat Rev Cancer 2(8), 584-93, 2002.

9. Wang F, Chen L, Zhang R, Chen Z, Zhu L. RGD peptide conjugated liposomal drug delivery system for enhance therapeutic efficacy in treating bone metastasis from prostate cancer. J Control Release 196, 222-33, 2014.

10. Ramanlal-Chaudhari K, Kumar A, Megraj-Khandelwal VK, Ukawala M, Manjappa AS, Mishra AK, Monkkonen J, Ramachandra-Murthy RS. Bone metastasis targeting: a novel approach to reach bone using Zoledronate anchored PLGA nanoparticle as carrier system loaded with Docetaxel. J Control Release 158(3), 470-8, 2012.

11. Krzeszinski JY, Wan Y. New therapeutic targets for cancer bone metastasis. Trends Pharmacol Sci 36(6), 360-73, 2015.

12. Miller K, Clementi C, Polyak D, Eldar-Boock A, Benayoun L, Barshack I, Shaked Y, Pasut G, Satchi-Fainaro R. Poly(ethylene glycol)-paclitaxelalendronate self-assembled micelles for the targeted treatment of breast cancer bone metastases. Biomaterials 34(15), 3795-806, 2013.

13. Yuasa T, Yamamoto S, Urakami S, Fukui I, Yonese J. Denosumab: a new option in the treatment of bone metastases from urological cancers. Onco Targets Ther 5, 221-9, 2012.

14. Li Y, Kong D, Ahmad A, Bao B, Sarkar FH. Targeting bone remodeling by isoflavone and 3,3'-diindolylmethane in the context of prostate cancer bone metastasis. PLoS One 7(3), e33011, 2012.

15. Mai J, Huang Y, Mu C, Zhang G, Xu R, Guo X, Xia X, Volk DE, Lokesh GL, Thiviyanathan V, Gorenstein DG, Liu X, Ferrari M, Shen H. Bone marrow endothelium-targeted therapeutics for metastatic breast cancer. J Control Release 187, 22-9, 2014.

16. Poologasundarampillai G, Wang D, Li S, Nakamura J, Bradley R, Lee PD, Stevens MM, McPhail DS, Kasuga T, Jones JR. Cotton-wool-like bioactive glasses for bone regeneration. Acta Biomater 10(8), 3733-46, 2014.

17. Hench LL, Roki N, Fenn MB. Bioactive glasses: Importance of structure and properties in bone regeneration. J Mol Struct 1073, 24-30, 2014.

18. Pathi SP, Lin DD, Dorvee JR, Estroff LA, Fischbach C. Hydroxyapatite nanoparticle-containing scaffolds for the study of breast cancer bone metastasis. Biomaterials 32(22), 5112-22, 2011.

19. Wang $Y$, Grainger DW. RNA therapeutics targeting osteoclast-mediated excessive bone resorption. Adv Drug Deliv Rev 64(12), 1341-57, 2012.

20. Konermann A, Staubwasser M, Dirk C, Keilig L, Bourauel C, Gotz W, Jager A, Reichert C. Bone substitute material composition and morphology differentially modulate calcium and phosphate release through osteoclast-like cells. Int J Oral Maxillofac Surg 43(4), 514-21, 2014.

21. Schroeder A, Heller DA, Winslow MM, Dahlman JE, Pratt GW, Langer R, Jacks T, Anderson DG. Treating metastatic cancer with nanotechnology. Nat Rev Cancer 12(1), 39-50, 2012.

22. Futakuchi M, Fukamachi K, Suzui M. Heterogeneity of tumor cells in the bone microenvironment: Mechanisms and therapeutic targets for bone metastasis of prostate or breast cancer. Adv Drug Deliv Rev 99(Pt B), 206-11, 2016. 
23. Clementi C, Miller K, Mero A, Satchi-Fainaro R, Pasut G. Dendritic poly(ethylene glycol) bearing paclitaxel and alendronate for targeting bone neoplasms. Mol Pharm 8(4), 1063-72, 2011.

24. Roodman GD. Mechanisms of bone metastasis. N Engl J Med 350(16), 1655-64, 2004

25. Blackburn G, Scott TG, Bayer IS, Ghosh A, Biris AS, Biswas A. Bionanomaterials for bone tumor engineering and tumor destruction. J Mater Chem B 1(11), 1519-1534, 2013.

26. Mohamed M, Borchard G, Jordan O. In situ forming implants for local chemotherapy and hyperthermia of bone tumors. J Drug Del Sci Tech 22(5), 393-408, 2012.

27. Brannon-Peppas L, Blanchette JO. Nanoparticle and targeted systems for cancer therapy. Adv Drug Deliv Rev 64, 206-212, 2012.

28. Singh R, Lillard JW, Jr. Nanoparticle-based targeted drug delivery. Exp Mol Pathol 86(3), 215-23, 2009.

29. Lammers $T$, Kiessling F, Hennink WE, Storm G. Drug targeting to tumors: principles, pitfalls and (pre-) clinical progress. J Control Release 161(2), 175-87, 2012.

30. Steichen SD, Caldorera-Moore M, Peppas NA. A review of current nanoparticle and targeting moieties for the delivery of cancer therapeutics. Eur J Pharm Sci 48(3), 416-27, 2013.

31. Ji W, Wang $H$, van den Beucken JJ, Yang F, Walboomers XF, Leeuwenburgh $S$, Jansen JA. Local delivery of small and large biomolecules in craniomaxillofacial bone. Adv Drug Deliv Rev 64(12), 1152-64, 2012.

32. Farokhzad OC, Cheng J, Teply BA, Sherifi I, Jon S, Kantoff PW, Richie JP, Langer R. Targeted nanoparticle-aptamer bioconjugates for cancer chemotherapy in vivo. Proc Natl Acad Sci U S A 103(16), 6315-20, 2006.

33. Clezardin P, Benzaid I, Croucher PI. Bisphosphonates in preclinical bone oncology. Bone 49(1), 66-70, 2011.

34. Yang L, Webster TJ. Nanotechnology controlled drug delivery for treating bone diseases. Expert Opin Drug Deliv 6(8), 851-64, 2009.

35. Gittens SA, Bansal G, Zernicke RF, Uludag H. Designing proteins for bone targeting. Adv Drug Deliv Rev 57(7), 1011-36, 2005.

36. Verron E, Khairoun I, Guicheux J, Bouler JM. Calcium phosphate biomaterials as bone drug delivery systems: a review. Drug Discov Today 15(13-14), 547-52, 2010.

37. Kurban S, Mehmetoğlu I. Osteoprotegerin, Rank ve Rank Ligandı. Turk J Biochem 32(4), 178-184., 2007.

38. Balasundaram G, Webster TJ. Nano-structured Biodegradable Ceramics for the Prevention and Treatment of Bone. NSTI-Nanotech, 2006.
39. Bae SE, Choi J, Joung YK, Park K, Han DK. Controlled release of bone morphogenetic protein (BMP)-2 from nanocomplex incorporated on hydroxyapatite-formed titanium surface. J Control Release 160(3), 676-84, 2012.

40. Choi SW, Kim JH. Design of surface-modified poly(D,L-lactide-coglycolide) nanoparticles for targeted drug delivery to bone. J Control Release 122(1), 24-30, 2007.

41. Miller K, Erez R, Segal E, Shabat D, Satchi-Fainaro R. Targeting bone metastases with a bispecific anticancer and antiangiogenic polymeralendronate-taxane conjugate. Angew Chem Int Ed Engl 48(16), 294954, 2009.

42. Ogawa K, Mukai T. Targeted imaging and therapy for bone metastases: control of pharmacokinetics of bone-targeted radiopharmaceuticals. J Drug Deliv Sci Tech 19(3), 171-176, 2009.

43. Chen H, Li G, Chi H, Wang D, Tu C, Pan L, Zhu L, Qiu F, Guo F, Zhu X. Alendronate-conjugated amphiphilic hyperbranched polymer based on Boltorn $\mathrm{H} 40$ and poly(ethylene glycol) for bone-targeted drug delivery. Bioconjug Chem 23(9), 1915-24, 2012.

44. Tautzenberger A, Kovtun A, Ignatius A. Nanoparticles and their potential for application in bone. Int J Nanomedicine 7, 4545-57, 2012.

45. Coleman R. Bone targeted treatments in cancer - The story so far. J Bone Oncology, 2016.

46. Li N, Song J, Zhu G, Shi X, Wang Y. Alendronate conjugated nanoparticles for calcification targeting. Colloids Surf B Biointerfaces 142, 344-50, 2016

47. Pareta RA, Taylor E, Webster TJ. Increased osteoblast density in the presence of novel calcium phosphate coated magnetic nanoparticles. Nanotechnology 19(26), 265101, 2008.

48. Hruby M, Etrych T, Kucka J, Forsterova M, Ulbrich K. Hydroxybisphosphonate-containing polymeric drug-delivery systems designed for targeting into bone tissue. J Appl Polym Sci 101(5), 31923201, 2006.

49. Ye WL, Zhao YP, Na R, Li F, Mei QB, Zhao MG, Zhou SY. Actively targeted delivery of doxorubicin to bone metastases by a $\mathrm{pH}$-sensitive conjugation. J Pharm Sci 104(7), 2293-303, 2015.

50. Daubine F, Cortial D, Ladam G, Atmani H, Haikel Y, Voegel JC, Clezardin P, Benkirane-Jessel N. Nanostructured polyelectrolyte multilayer drug delivery systems for bone metastasis prevention. Biomaterials 30(31), 6367-73, 2009.

Received: 27.07.2016

Accepted: 04.08.2016 